\title{
Sprawozdanie
}

\section{Zjazd Katedr i Zakładów Prawa Konstytucyjnego nt.: Zmiany wspótczesnych systemów parlamentarnych, Józefów 9-11 czerwca 2011 r.}

Już po raz 53, tym razem w podwarszawskim Józefowie, na corocznym Zjeździe Katedr i Zakładów Prawa Konstytucyjnego spotkali się pracownicy naukowi katedr i zakładów prawa konstytucyjnego polskich szkół wyższych oraz innych instytucji naukowych związanych z konstytucjonalizmem. Tegoroczny Zjazd, który miał miejsce w dniach 9-11 czerwca 2011 r., zorganizowany został przez Zakład Systemów Politycznych Wydziału Dziennikarstwa i Nauk Politycznych Uniwersytetu Warszawskiego. Uczestnikami Zjazdu, obok grona prawników konstytucjonalistów oraz politologów, była także liczna grupa osób zajmujących najwyższe stanowiska państwowe oraz piastujących urzędy sędziowskie w sądach i Trybunale Konstytucyjnym.

W imieniu organizatorów uczestników Zjazdu powitał prof. dr hab. T. Mołdawa - przewodniczący Rady Naukowej Instytutu Nauk Politycznych Uniwersytetu Warszawskiego. Odnosząc się do wieloletniej tradycji organizacji Zjazdów i podkreślając ogromny wpływ jego uczestników na życie publiczne, a przede wszystkim rozwój nauki prawa konstytucyjnego, prof. T. Mołdawa wyraził podziękowanie za powierzenie organizacji Zjaz$\mathrm{du}$ i zadowolenie $\mathrm{z}$ dużego zainteresowania przedstawicieli nauki spotkaniem, którego tematem była problematyka Zmian współczesnych systemów parlamentarnych. Następnie gości przywitali: Dziekan Wydziału Dziennikarstwa i Nauk Politycznych Uniwersytetu Warszawskiego - prof. dr hab. J. Adamowski oraz Kierownik Zakładu Systemów Politycznych Wydziału Dziennikarstwa i Nauk Politycznych - prof. dr hab. Z. Kiełmiński. Obaj przedstawiciele organizatorów życzyli uczestnikom owocnych obrad, wielu konstruktywnych konkluzji i burzliwych dyskusji, także poza oficjalnymi częściami Zjazdu.

Pierwszej sesji, której tematem była Konceptualizacja systemów parlamentarnych, przewodniczył prof. dr hab. W. Sokolewicz. Jako pierwsza wystąpi- 
ła prof. dr hab. M. Kruk Jarosz, przedstawiając referat zatytułowany Wprowadzenie do parlamentarnego systemu rządów. Prelegentka skoncentrowała się na czterech zagadnieniach: ustaleniu zakresu oraz treści pojęcia „system rządów” i „parlamentarny system rządów”; systemie rządów parlamentarnych w kontekście systemu organów państwa; genezie parlamentarnego systemu rządów oraz giętkości i cech konstytutywnych parlamentarnego systemu rządów. Autorka zwróciła uwagę na różnorodność odmian systemów parlamentarnych prowadzących do trudności definicyjnych, których jednym z przejawów jest używanie różnych nazw - parlamentarno-gabinetowy, parlamentarno-prezydencki, kanclerski, zracjonalizowany na określenie omawianego systemu.

Kolejny zajmujący referat - Oddziatywanie integracji europejskiej na ustroje państw członkowskich Unii Europejskiej - przedstawił prof. dr hab. K. Wojtyczek. Autor podjął próbę udzielenia odpowiedzi na pytania, czy i w jaki sposób kształtowanie się struktur Unii Europejskiej oddziaływuje na państwa członkowskie, na czym polega wpływ integracji europejskiej na ustroje państwowe i czy możliwe jest ustalenie ogólnych prawidłowości w tym zakresie odnoszących się do wszystkich państw członkowskich. Szczególną uwagę prof. K. Wojtyczek zwrócił na rolę zasady pomocniczości w procesie przekazywania kompetencji między Unią Europejską a państwami członkowskimi, co może zwiększać efektywność działania władzy publicznej i stwarzać poczucie możliwości przezwyciężenia erozji państwa. Integracja europejska, zdaniem Autora, prowadzi do europeizacji władzy ustrojodawczej, wyrażającej się m.in. w utracie przez państwa członkowskie monopolu w zakresie samodzielnego normowania ustroju władzy publicznej oraz wspólnym sprawowaniu części władzy ustrojodawczej przez państwa członkowskie. Ponadto zasada nadrzędności konstytucji krajowych koliduje z zasadą pierwszeństwa prawa Unii Europejskiej, która musi być rozstrzygana przez państwa członkowskie. Referent podkreślił także zmianę relacji między władzami państwowymi: parlamentem a rządem, której jednym z przejawów jest przełamanie monopolu egzekutywy w dziedzinie polityki zagranicznej. Członkostwo w Unii narusza dotychczasową równowagę między władzami, wymuszając działania zmierzające do ustanowienia nowych regulacji ustalających równowagę władz na nowym poziomie.

Jako ostatni w sesji przedpołudniowej zabrał głos prof. dr hab. R. Małajny, przedstawiając referat Rozdział władzy w systemie parlamentarnym. Referent 
przedstawił zagadnienie na tle praktyki konstytucyjnej wybranych państw zachodnich, a także Polski. Trudności w udzieleniu odpowiedzi na pytanie, czy system parlamentarny opiera się na zasadzie podziału władz, widział w dowolności w posługiwaniu się pojęciem „podział władzy” i jego pojemną formułą - dopuszczającą szereg rozwiązań ustrojowych. Podsumowując swoją wypowiedź, autor stwierdził, iż odmówienie systemowi parlamentarnemu realizacji zasady podziału władz musiałoby prowadzić do milczącego przyznania, iż fundamentem systemu jest zasada jednolitości władzy państwowej, a powyższa teza trudna byłaby do obrony.

Ostatnim elementem przedpołudniowej sesji była ożywiona dyskusja, w której podkreślano istotę podnoszonych w referatach problemów. Co istotne szczególne zainteresowanie referatami można było zaobserwować wśród młodych pracowników nauki, którzy z wielką dociekliwością zadawali prelegentom pytania oraz podejmowali próby formułowania własnych tez w zakresie poruszanych w wystąpieniach zagadnień.

Tematem popołudniowej sesji była Polska aplikacja systemów parlamentarnych. Przewodnictwo nad obradami powierzono prof. dr hab. P. Sarneckiemu. Jako pierwszy referat pt. Parlamentaryzm III RP: aksjologia konstytucyjna a dylematy praktyki ustrojowej przedstawił prof. dr hab. J. Jaskiernia. Głównym tematem rozważań prelegenta stała się kwestia aksjologii konstytucyjnej parlamentaryzmu i wiążące się z nią dylematy ustrojowe towarzyszące funkcjonowaniu władzy ustawodawczej. Zdaniem prof. J. Jaskierni parlament eksponuje wartość, jaką jest suwerenność Narodu, jest także elementem szeregu wartości konstytucyjnych. W kontekście członkowstwa w Unii Europejskiej parlament polski, jak i inne parlamenty narodowe, uzyskał nowe usytuowanie w systemie decyzyjnym Unii Europejskiej. Dało to nowy wymiar parlamentaryzmowi, przynosząc istotne konsekwencje dla legitymizacji Unii.

Jako ostatni w tej części obrad głos zabrał dr hab. J. Szymanek. Przedstawił on referat Elementy racjonalizacji w konstrukcji parlamentarnego systemu rząów: analiza rozwiązań zawartych $w$ Konstytucji $R P$. Omówienie elementów racjonalizacji systemu parlamentarnego prelegent poprzedził analizą procesu racjonalizacji i wskazaniem różnorodności podejść w definiowaniu pojęcia racjonalizacji. Referent skonstatował, iż racjonalizacja, rozumiana jako zagwarantowanie parlamentowi wysokiej pozycji, jest rozwiązaniem w Polsce tradycyjnym, a jej rozwój zmierza w kierunku rewaloryzacji 
stanowiska kolegialnego organu władzy wykonawczej oraz wzmocnienia pozycji ustrojowej Prezydenta. W sformułowanych postulatach de lege ferenda prelegent wskazywał na konieczność większego uwypuklenia praktyki politycznej i kształtujących się na jej bazie zwyczajów i obyczajów politycznych.

Sobotniej i ostatniej już sesji Zjazdu przewodniczył prof. dr hab. M. Grzybowski. Tematem przewodnim była Europejska modyfikacja systemów parlamentarnych. Pierwszy z prelegentów, prof. dr hab. A. Antoszewski, przedstawił referat zatytułowany Parlamentaryzm jako przestrzeń rywalizacji międzypartyjnej. W ocenie referenta tym, co wpływa na zróżnicowanie współczesnego parlamentaryzmu, jest system partyjny i jego kształt - zarówno na płaszczyźnie parlamentarnej, jak i gabinetowej. Parlamentaryzm może być, zdaniem prelegenta, potraktowany jako przestrzeń rywalizacji politycznej, rozumianej jako możność uczestniczenia w rządzie, przy założeniu wszakże, iż partie przekroczą próg wyborczy i dysponują potencjałem koalicyjnym. Umożliwia on realizację dwóch celów - reprezentatywności i efektywności polityki. Referent zwrócił również uwagę na niebezpieczeństwo osłabienia politycznego efektu wyborów w przypadku złożenia decyzji o powołaniu i utworzeniu rządu w ręce elit partyjnych.

Następnie prof. dr hab. K. Wójtowicz przedstawił referat Rola parlamentów narodowych $w$ świetle postanowień Traktatów stanowiących podstawe Unii Europejskiej. Reformy Unii Europejskiej przyniosły, zdaniem prelegenta, wzmocnienie roli parlamentów narodowych, dając podstawy do aktywnego oddziaływania parlamentów narodowych na funkcjonowanie Unii Europejskiej i prowadząc do łagodzenia „deficytu demokracji”. Sprawdzianem przyjętych rozwiązań będzie skuteczność wykorzystywania przez same parlamenty wynikających z reformy możliwości, potrzebne jest jednak wprowadzenie na gruncie prawa krajowego odpowiednich zmian dostosowawczych i lepszego przygotowania parlamentarzystów do analizowania dostarczanych im informacji i podejmowania działań na płaszczyźnie krajowej oraz forum Unii.

$\mathrm{Na}$ tle wygłoszonych referatów rozgorzała ciekawa dyskusja, w trakcie której zwracano uwagę na dowolność posługiwania się pojęciami, które $\mathrm{w}$ powszechnym rozumieniu są znane, jednak mogą być odmiennie definiowane, co na gruncie prawa może powodować zbyt daleko idącą swobodę interpretacyjną. Szereg pytań dotyczyło systemu partyjnego, a także poszukiwania odpowiedzi na banalne z pozoru pytanie, czym właściwie jest partia 
polityczna i jaki jej model powinien funkcjonować w ramach polskiego systemu prawnego. Dyskutanci koncentrowali się również na perspektywach rozwoju parlamentów narodowych w świetle reform ustrojowych Unii Europejskiej i wynikających zmian w realizacji funkcji parlamentów. Pojawiające się podczas dyskusji tezy oraz spostrzeżenia z pewnością mogły stanowić ciekawy asumpt do podjęcia badań naukowych w tej - wydawałoby się - szeroko omawianej w doktrynie materii.

Na zakończenie Zjazdu w imieniu organizatorów głos zabrał prof. dr hab. Z. Kiełmiński. Podziękował uczestnikom, a przede wszystkich prelegentom, za wysoki merytoryczny poziom referatów i dyskusji, a tym samym wkład w rozwój dyskursu naukowego.

Organizację kolejnego, już 54 Zjazdu Katedr i Zakładów Prawa Konstytucyjnego - podczas zwyczajowo organizowanego w ramach Zjazdu zebrania Kierowników Katedr - powierzono Katedrze Prawa Konstytucyjnego Wydziału Prawa w Białymstoku. Z niecierpliwością oczekiwać będziemy na wskazanie miejsca, w którym przyjdzie się nam spotkać kolejnym razem, oraz tak samych prelegentów, jak i przedstawianych przez nich, w ramach wygłaszanych referatów, zagadnień.

Joanna Juchniewicz (Uniwersytet Warmińsko-Mazurski)

Przemysław Mijal (Uniwersytet Szczeciński) 